\title{
SISTEM INFORMASI PEMBENIHAN KENTANG PADA BALAI BENIH INDUK (BBI) KABUPATEN KERINCI
}

\author{
Yulia ${ }^{1)}$, Tri A. Sundara ${ }^{2)}$, \\ 1)Jurusan Sistem Informasi, STMIK Indonesia Padang \\ Jalan Khatib Sulaiman Dalam 1, Padang, 25136 \\ 2) Jurusan Sistem Informasi, STMIK Indonesia Padang \\ Jalan Khatib Sulaiman Dalam 1, Padang, 25136 \\ E-Mail : : yuliapira@gmail.com ${ }^{1)}$; tri.sundara@stmikindonesia.ac.id $^{2)}$
}

\begin{abstract}
ABSTRAK
Perkembangan teknologi komputer di Indonesia saat ini cukup berkembang pesat. Sejalan dengan itu pengembangan Balai Benih Induk (BBI) kentang pun mengalami perkembangan, seperti halnya pada Balai Benih Induk (BBI) kentang Kabupaten Kerinci. Pengolahan data pembenihan kentang dan laporan perkembangan pembenihan belum terkomputerisasi karena masih menggunakan Microsoft Excel, sehingga menyebabkan beberapa permasalahan diantaranya dalam pembuatan laporan perkembangan pembenihan kentang dan pencarian data membutuhkan waktu yang cukup lama. Hal ini menyebabkan lemahnya pengolahan sistem pengolahan data pembenihan dan pembuatan laporan perkembangan pembenihan kentang Kabupaten Kerinci. Melihat permasalahan di atas maka dibuatkan sistem informasi pembenihan kentang pada Balai Benih Induk (BBI) menggunakan bahasa pemrograman $\mathrm{C} \#$ yang sudah menggunakan database dan menggunakan Crystal Report untuk membantu dalam pembuatan laporan perkembangan pembenihan kentang pada Balai Benih Induk (BBI) Kentang Kabupaten Kerinci.
\end{abstract}

Kata Kunci : Sistem Informasi, pembenihan kentang, Kerinci, C\#, Crystal Report.

\begin{abstract}
Development of computer technology in Indonesia is growing rapidly enough. In line with the development of the Master Seed Center (Balai Benih Induk, BBI) potato also experienced growth, as well as on the porch of foundation seeds (BBI) potato Kerinci. Data processing potato seeding and seeding progress report is not computerized because they still use Microsoft Excel, causing them some problems in the manufacture of potato seeding progress report and data search requires considerable time. It weakens the systems processing data processing and report generation seeding potato seeding progress Kerinci. See the above problems then made the information system seeding potatoes on Seed Holding (BBI) using $C$ \# are already using the database and using Crystal Report to assist in making progress report seeding potatoes On Seed Parent (BBI) potatoes district of Kerinci.
\end{abstract}

Keywords : Information System, Potato Seed, Kerinci, C\#, Crystal Report

\section{PENDAHULUAN}

Balai Benih Induk Kentang (BBI Kentang) merupakan sebuah instansi yang bergerak dibidang pembenihan yang berada di bawah naungan Dinas Pertanian Tanaman Pangan. BBI Kentang Kayu aro berlokasi di Jl. Raya Batang Sangir, Kecamatan Kayu Aro, Kabupaten Kerinci, Provinsi Jambi. Kawasan ini secara agroekositem memang cocok sebagai sentra produksi kentang, Balai Benih Induk (BBI) sangat penting dalam mendukung pengembangan produksi komoditas ataupun budidaya tanaman, untuk meningkatkan produktivitas pertanian khususnya di kabupaten kerinci, maka Balai Benih Induk (BBI) berusaha menghasilkan benih bermutu varietas unggul ditingkat lapangan.

Benih kentang yang di produksi pada Balai Benih Induk (BBI) hanya satu jenis yaitu varietas Granola. Varietas Granola sangat cocok ditanam pada dataran tingggi yang berada pada ketinggian $1.483 \mathrm{~m}$. Varietas Granola yang dikembangkan pada Balai Benih Induk (BBI) memiliki beberapa kelas yaitu G0, G1, G2, dan G3. Maka, yang dibudidayakan petani adalah kelas G3.

Dalam peningkatan produktivitas benih kentang Balai Benih Induk (BBI) harus meningkatkan faktor Sumber Daya Manusia (SDM), dan faktor pendukung lain seperti Teknologi dan Sistem Informasi. Saat ini 
teknologi dan sistem informasi sangat berperan aktif di bidang perkantoran salah satunya Balai Benih Induk (BBI) dalam pengolahan data pembenihan kentang. Beberapa sistem informasi yang dapat dikembangkan dalam pembenihan kentang di antaranya bank data, proses kualifikasi, dan analisis data pembibitan. [1] Data spasial dan estimasi produksi juga dapat ditambahkan untuk memperkaya informasi. [2] Selain itu, dapat juga dikembangkan suatu sistem manajemen risiko. [3]

Berdasarkan survey yang dilakukan sebelumnya, Balai Benih Induk (BBI) belum memiliki teknologi informasi yang memadai untuk mendukung seluruh aktivitas sistem informasi. Pengolahan data pembenihan kentang masih dilakukan secara manual. Staf Balai Benih Induk (BBI) memanfaatkan Microsoft Excel dalam pengolahan data pembenihan kentang dan penyimpanan laporan dalam bentuk arsip dan catatan harian.

Dari permasalahan diatas mengakibatkan Staf Balai Benih Induk (BBI) kesulitan dalam melakukan pemrosesan data pembenihan kentang sehingga dalam pembuatan laporan sering terlambat karena masih dilakukan secara manual dan tidak terkomputerisasi.

Untuk mempermudah Staf Balai Benih Induk (BBI) dalam pencarian data dan informasi atau dalam pembuatan laporan dalam format standar, maka Staf TU Balai Benih Induk (BBI) membutuhkan sebuah aplikasi yang dapat membantu dan mempermudah Staf Balai Benih Induk (BBI) dalam mengatasi masalah tersebut.

\section{TINJAUAN PUSTAKA}

\subsection{Pembenihan}

Menurut Paristiyanti Nurwardani [4] "Pembenihan tanaman adalah suatu proses penyediaan bahan tanaman yang berasal dari benih tanaman (biji tanaman berkualitas baik dan siap untuk ditanam) atau bahan tanaman yang berasal dari organ vegetatif tanaman untuk menghasilkan bibit (bahan tanaman yang siap untuk ditanam di lapangan”.

\subsection{Kentang}

Menurut Kusrini [5]: "Kentang (solanum tuberosum L.) termasuk jenis tanaman sayuran semusim, berumur pendek dan berbentuk perdu atau semak. Kentang termasuk tanaman semusin kareana hanya satu kali berproduksi dan setelah itu mati. Umurnya relatif pendek, hanya 90-180 hari."

Spesies solanum tuberosum L. memiliki banyak varietas. Umur tanaman kentang bervariasi menurut varietasnya. Kentang varietas genjah berumur 90-120, varietas medium berumur
150-180 hari, dan varietas dalam berumur 150-180 hari.

\section{3. Sistem informasi pembenihan kentang}

Pengolahan data pembenihan kentang pada Balai Benih Induk (BBI) yang dilakukan yaitu masih menggunakan Microsoft Excel diperbaharui dengan sistem baru yaitu dengan menggunakan sistem informasi bahasa pemograman C\# yang dapat menghasilkan laporan yang akurat, tepat waktu dan efisien serta bermanfaat. Sistem informasi pembenihan kentang pada Balai Benih Induk (BBI) ini nantinya akan dikelola oleh bagian Staf TU yang menghasilkan laporan perkembangan benih, perhari, perbulan dan setiap tahunnya. Sistem informasi pembenihan kentang membutuhkan entri data benih, entri data gudang, entri data kelas, entri data sertifikatlabel, tersimpan ke dalam database.

\subsection{Balai Benih Induk (BBI)}

Balai benih induk (BBI) berdiri pada tahun 2002 dan diresmikan pada tahun 2007. Balai Benih Induk (BBI) merupakan salah satu instansi sangat penting dalam mendukung pengembangan produksi komoditas ataupun budidaya tanaman Balai Benih Induk (BBI) mnghasilkan benih bermutu varietas unggul di tingkat lapangan, diperbanyak dan disebarkan. suatu daerah berkomitmen mengembangkan kawasan dan sentra produksi suatu komoditas, maka pembangunan dan pengembangan balai benih merupakan prioritas.

Menyadari akan pentingnya peranan instansi perbenihan tersebut, maka sudah lama pemerintah Provinsi Jambi maupun Kabupaten Kerinci mewujudkan berdirinya Balai Benih Induk Kentang (BBI Kentang) Kayu Aro. BBI Kentang Kayu Aro berlokasi di Batang Sangir, Jl. Raya Batang Sangir, kecamatan Kayu Aro (kabupaten Kerinci, Provinsi Jambi). Kawasan ini secara agroekosistem memang cocok sebagai sentra produksi kentang, merupakan dataran tinggi yang berada pada ketinggian 1.483 meter dpl dengan curah hujan rata-rata $1.500-2.000$ $\mathrm{mm} /$ tahun. Karakteristik tanah adalah jenis tanah andosol dengan tekstur tanah remah dan berwarna hitam, tanah mempunyai kemasaman normal dengan $\mathrm{pH}$ tanah 5,5-6,5. Lahan yang dimiliki oleh BBI Kentang saat ini seluas 14,7 Ha yang terdiri dari lahan untuk perbanyakan benih seluas $13 \mathrm{Ha}$ dan 1,7 Ha untuk bangunan dan fasilitas pendukung.

Visi Balai Benih Induk (BBI) Kentang Kayu Aro adalah mewujudkan sentra pembenihan kentang se-Sumatera dan menghasilkan benih kentang yang berkualitas tinggi. 
Misi Balai Benih Induk (BBI) Kentang adalah:

1) Menyediakan benih kentang yang berkualitas dengan harga yang terjangkau, dan

2) Membina penangkar benih kentang agar dapat bersaing dengan penangkar di daerah lainnya.

Siklus hidup sistem informasi dimulai dari fase perencanaan, fase pengembangan (investigasi, analisis, desain, implementasi) dan dievaluasi secara terus-menerus untuk menetapkan apakah sistem tersebut masih layak diaplikasikan. Jika tidak maka sistem tersebut akan diganti dengan yang baru akan dimulai dari perencanaan kembali seperti dengan pada gambar 1 dibawah ini:

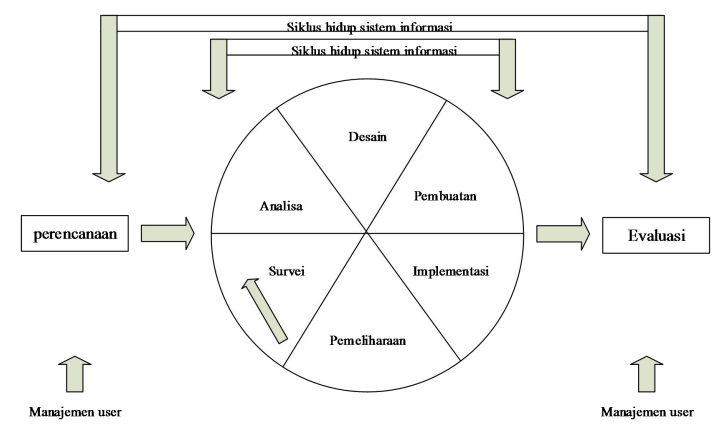

Gambar 1. Siklus Hidup Sistem Informasi

\section{METODE}

Dalam proses penelitian penulis menggunakan beberapa metode yang mendukung. Antara lain :

1. Penelitian lapangan (Field Research)

Yaitu penelitian yang dilakukan langsung dilapangan, dalam hal ini penulis mendapatkan data dari melakukan wawancara langsung dengan salah satu staf yang ada pada Balai Benih Induk, dan pada bagian pemasaran dan termasuk kepala Balai Benih Induk.

2. Penelitian perpustakaan (Library Research)

Penelitian yang dilakukan membaca buku-buku tentang sistem informasi manajemen, tentang Balai Benih Induk. Dalam hal ini dilakukan dengan cara mengutip referensi-referensi, landasan teori yang berupa literatur untuk mendukung dan mendapatkan hasil bahasan yang dilakukan.

3. Penelitian Laboratorium (Laboratory Research)

Melakukan penelitian dilabor dengan data yang telah dikumpulkan kemudian diolah dengan menggunakan perangkat keras (hardware) dan perangkat lunak (software) komputer, untuk dapat dilakukan pengujian dan pengimplementasian hasil program.

\section{HASIL DAN PEMBAHASAN}

Pada analisis sistem informasi ini, akan diuraikan sistem informasi yang utuh ke dalam bagian-bagian komponennya dengan maksud untuk mengidentifikasi dan mengevaluasi permasalahan, hambatan-hambatan yang terjadi dan kebutuhan yang diharapkan, sehingga dapat diusulkan perbaikannya.

Sistem yang diusulkan memperbaiki sistem kerja yang berjalan sehingga memudahkan bagi pemakai dalam menyelesaikan tugas dibidang pengolahan data dan laporan. Karena pengolahan data dan laporan yang dilakukan sekarang ini kurang efektif dan efesien.

Setelah dilakukan penganalisaan terhadap sistem yang sedang berjalan dapat dilihat cara kerjanya yang masih manual denagn aliran Sistem Informasi sebagai berikut:

1. Personil : (Anggaran Perencanaan Belanja Daerah)APBD, (Badan Pengawas Sertifikat Benih) BPSB, Gudang, Staf TU, Pimpinan.

2. APBD memberikan data benih kepada Staf TU

3. Staf TU memberikan data benih untuk di cek kualitas dari benih kepada BPSB

4. BPSB menerima data yang diberikan oleh Staf TU, data tersebut dicek dan menghasilkan sertifikat label benih, label benih diberikan kepada Staf TU.

5. Gudang memeberikan data hasil panen kepada Staf TU.

6. Staf TU menerima label benih dan data hasil panen, data tersebut diproses menghasilkan laporan perbulan dan pertahun sebanyak 3 rangkap, serta setifikat laporan benih

7. Staf TU memberikan label benih pada gudang.

8. Staf TU memeberikan 3 rangkap laporan laporan perbulan dan laporan pertahun kepada Pimpinan.

9. Pimpinan menerima 3 ramgkap laporan laporan perbulan dan laporan pertahun untuk di setujui di berikan 2 rangkap kembali kepada Staf TU, 1 rangkap di arsipkan oleh pimpinan

10. Staf TU menerima 2 rangkap laporan laporan perbulan dan laporan pertahun, 1 rangakap diberikan kepada APBD dan 1 Rangkap di arsipkan oleh Staf TU. 


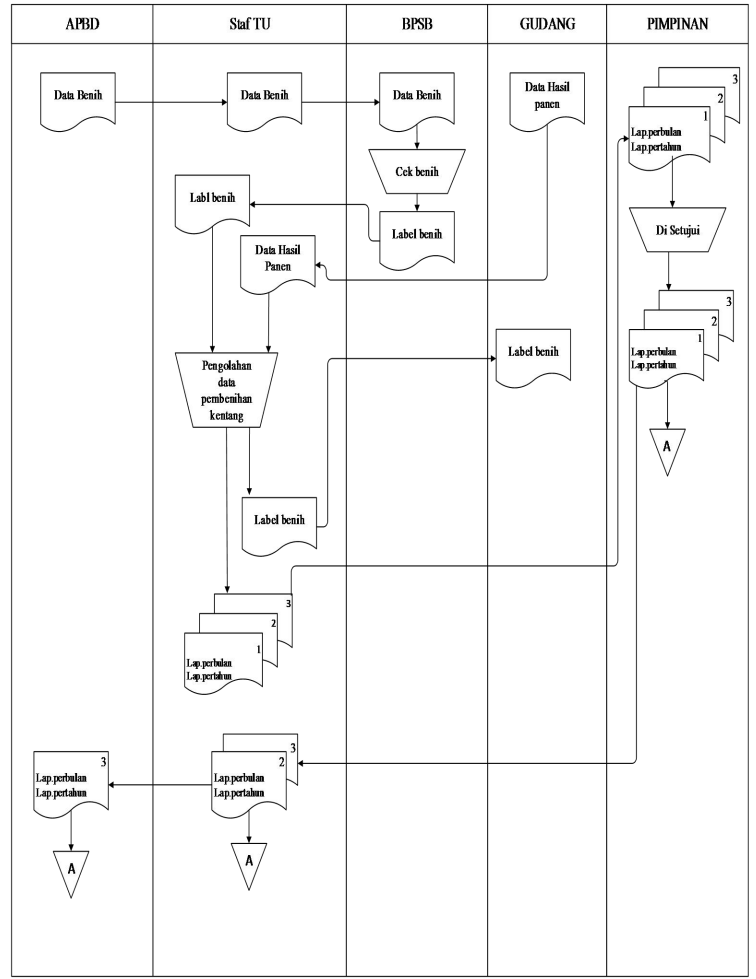

Gambar 2. Aliran Sistem Yang Sedang Berjalan Pada Sistem Informasi Pengolahan Data Benih

\subsection{Aliran Sistem Informasi yang diusulkan}

Melihat kinerja sistem yang sedang berjalan, maka penulis mengajukan perbaikan sistem yang bertujuan untuk memperbaiki sistem yang ada. Pada aliran sistem informasi yang diusulkan ini dilakukan perubahan terutama dalam pengolahan data dan pembuatan laporan. Tujuannya adalah agar permasalahan pada sistem yang lama dapat teratasi seperti pembuatan laporan dengan menggunakan program aplikasi berbasis database.

Database berperan penting dalam aplikasi komputer, karena database merupakan media yang akan menampung data-data yang dimasukkan melalui form-form entrian data. Keterkaitan data-data yang dimasukkan kedalam database memberikan kemudahan user dalam penyajian laporan, dan jika ingin melakukan pengoreksian dan penghapusan data akan lebih mudah dilakukan dengan aplikasi komputer karena pencarian data begitu cepat dan akurat. Adapun prosedur aliran sistem informasi pengolahan laporan pembenihan pada Balai Benih Induk (BBI) yang diusulkan adalah:

1. Personil : APBD, BPSB, Gudang, Staf TU, Pimpinan. Staf TU

2. APBD memberikan data benih kepada

3. Staf TU memberikan data benih untuk di cek kualitas dari benih kepada BPSB

4. BPSB menerima data yang diberikan oleh Staf TU, data tersebut dicek dan menghasilkan label benih benih, setifikat label benih diberikan kepada Staf TU.

5. Gudang memeberikan data hasil panen kepada Staf TU.

6. Staf TU mengolah data yang diberikan oleh BPSB dan gudang serta menyimpannya secara otomatis kedalam database dan menghasilkan, laporan perbulan dan pertahun sebanyak 3 rangkap.

7. Staf TU memberikan label benih benih pada gudang

8. Staf TU memberikan 3 rangkap laporan perbulan dan laporan pertahun kepada Pimpinan.

9. Pimpinan menerima 3 ramgkap laporan perbulan dan laporan pertahun untuk di setujui di berikan 2 rangkap kembali kepada Staf TU, 1 rangkap di arsipkan oleh pimpinan

10. Staf TU menerima 2 rangkap laporan Harian, laporan perbulan dan laporan pertahun, 1 rangakap diberikan oleh APBD dan 1 Rangkap di arsip oleh Staf TU.

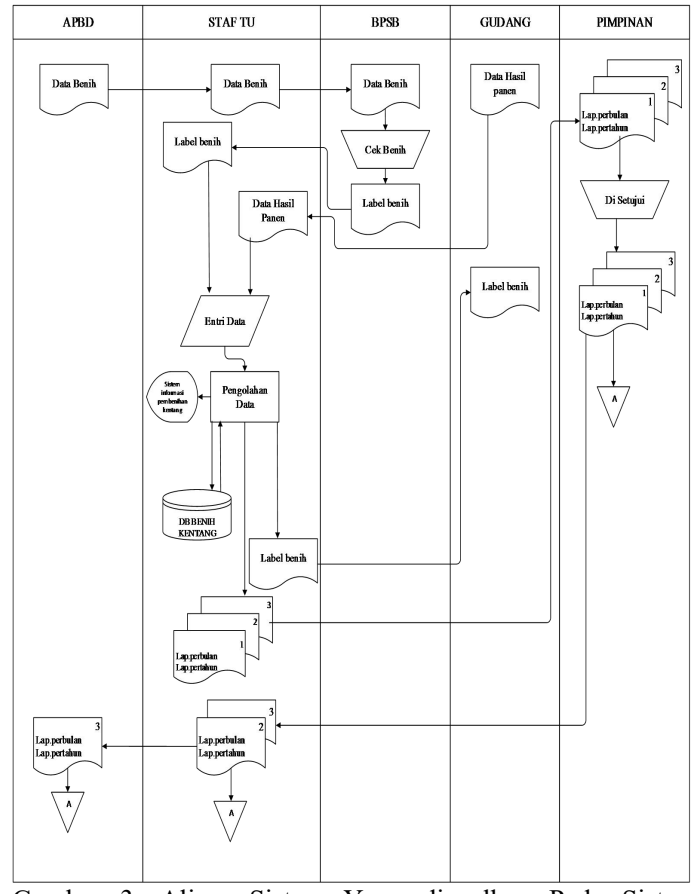

Gambar 3. Aliran Sistem Yang diusulkan Pada Sistem Informasi Pengolahan Data Benih

\subsection{Hasil analisis}

Aliran sistem informasi (ASI) pada sistem yang diusulkan ini tidak hanya jauh berbeda dengan aliran sistem informasi yang sedang berjalan. Hanya saja pada sistem yang sedang berjalan, pada bagian Staf TU melakukan pengolahan data dan laporan pembenihan secara terkomputerisasi dengan menggunakan database sebagai tempat penyimpanan yang kemudian diolah sehingga menghasilkan laporan-laporan pembenihan yang dibutuhkan. 
Adapun hasil yang didapat pada sistem yang diusulkan adalah sebagai berikut:

1. Proses pengolahan data sudah terkomputerisasi, sehingga proses pengolahan data akan lebih cepat dan akurat.

2. Data tersimpan dalam database dengan rapi selama sistem digunakan sehingga data dapat diambil bila diperlukan (memiliki backup).

3. Proses pembuatan laporan akan lebih cepat dan akurat

4. Memperkecil peluang manipulasi data

Dengan adanya perbaikan terhadap sistem yang lama, diharapkan pengolahan data dan laporan pada balai benih induk akan menjadi lebeih efektif dan efesien sehingga dapat meningkatkan kinerja.

\subsection{PERANCANGAN SISTEM}

Sistem Informasi yang dirancang adalah sebagai berikut:

A. Desain Secara Global

1. Hierarchy Plus Input Process Output (HIPO)

HIPO (Hierarchy Plus Input Process Output) yang dirancang untuk laporan pembenihan kentang pada Balai Benih Induk (BBI) Kentang Kabupaten Kerinci dapat di lihat pada gambar 4 berikut ini:

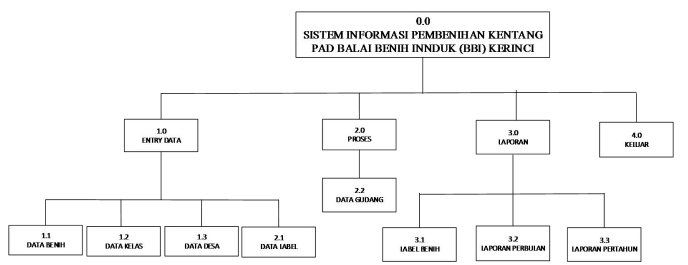

Gambar 4. Hierarchy Plus Input Process Output sistem informasi pemenihan kentang pada Balai Benih Induk (BBI) Kentang Kabupaten Kerinci.

Rancangan aplikasi sistem informasi pemenihan kentang pada balai benih induk (BBI) Kentang Kabupaten Kerinci terdiri dari entri data, proses, laporan dan keluar. Pada rancangan entri data terdapat rancangan subs-sub bagian yaitu rancangan entri data benih, data desa, data kelas,data label pada rancangan proses terdapat rancangan sertifikat dan gudang, pada rancangan laporan terdapat rancanagn sub-sub bagian yaitu rancangan sertifikat label benih, laporan perbulan, laporan pertahun serta rancangan menu keluar yang berarti keluar dari program tersebut.

\section{Context Diagram (CD)}

Berikut Context Daigram atau DFD level 0 yang menggambarkan garis besar dari sistem informasi pembenihan kentang yang melibatkan 5 entitas yaitu APBD bagian pemasok, BPSB bagian pengecekkan benih, Staf TU, gudang, dan pimpinan.

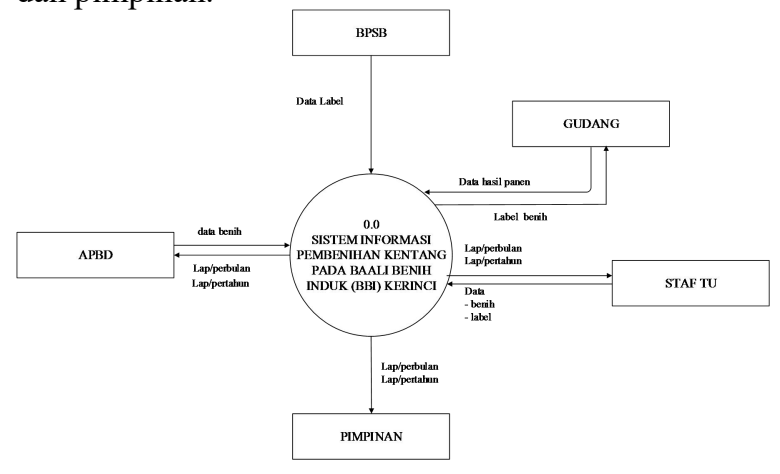

Gambar 5. Context Diagram sistem informasi pembenihan kentang pada Balai Benih Induk (BBI) kentang Kabupaten Kerinci

Pada sistem informasi pembenihan kentang pada balai benih induk (BBI) kentang Kkabupaten Kkerinci :

1) APBD bagian pemasok menyerahkan data benih ke sistem dan alur baliknya laporan pebulan dan laporan pertahun

2) Gudang menyerahkan dara hasil panen ke sistem dan alur baliknya sertifikat label benih

3) BPSB menyerahkan sertifikat label benih ke sistem

4) Staf TU menyerahkan data hasil panen dan sertifikat label ke sistem alur baliknya sertefikat label benih, laporan perbulan dan laopran pertahun

5) Pimpinan menerima laporan perbualan dan pertahun.

3. Data Flow Diagram (DFD)

Data Flow Diagram (DFD) sistem informasi pembenihan kentang pada bali benih induk (BBI) kentang Kabupaten Kerinci dapat dilihat pada gambar 6 :

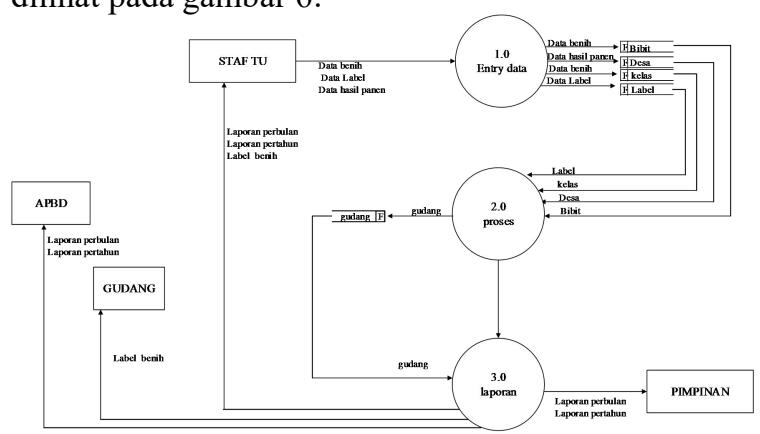

Gambar 6. Data Flow Diagram (DFD) sistem informasi pembenihan kentang pada Balai Benih Induk (BBI) kentang Kabupaten Kerinci.

Pada sistem informasi pembenihan kentang pada Balai Benih Induk (BBI) kentang Kabupaten Kkerinci : 
1) APBD bagian pemasok menyerahkan data benih ke Staf TU dan menerima laporan perbulan dan laporan pertahun

2) Gudang menyerahkan dara hasil panen ke Staf TU dan menerima sertigikat label benih. Staf TU

3) BPSB menyerahkan sertifikat label ke

4) Staf TU menyerahkan data hasil panen dan sertifikat label ke sistem alur baliknya sertifikatlabel benih, laporan perbulan dan laporan pertahun

5) Pimpinan menerima sebanyak 3 rangkap laporan perbualan dan pertahun, laporan tersebut di tanda tangani oleh pimpinan setelah di tanda tanganni kemudian pimpinan menyerahkan kembali laporan kepada Staf TU 2 rangkap dan rangkap di arsipkan.

4. Entity Relantionship Diagram (ERD)

Entity Relantionship Diagram (ERD) digunakan untuk menjelaskan hubungan dari beberapa file yang ada dalam program. Dari tiap-tiap file tersebut mempunyai beberapa field. Field dihubungkan dengan field yang telah ditentukan. ERD ini dapat dilihat pada gambar 7:

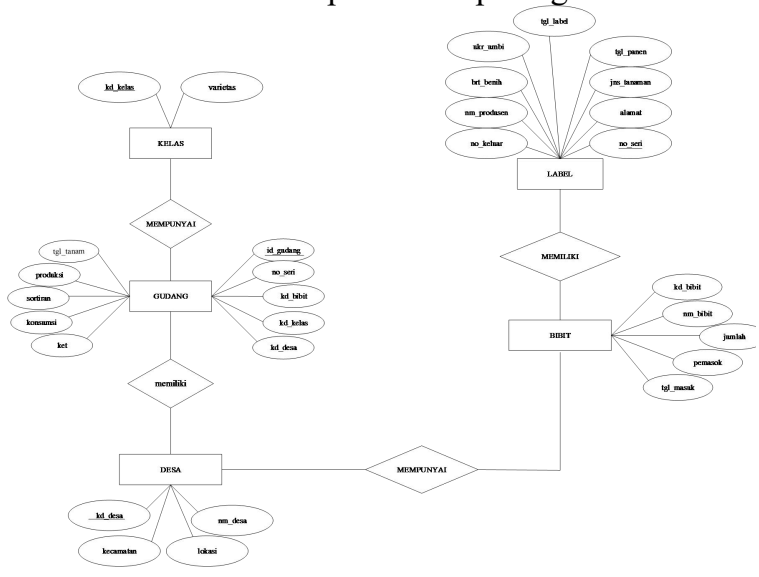

Gambar 7. Entity Relantionship Diagram (ERD) sistem informasi pembenihan kentang pada Balai Benih Induk (BBI) kentang Kabupaten Kerinci.

Adapun bentuk relasi file dari pembenihan kentang pada Balai Benih Induk (BBI) kentang Kabupaten Kerinci dapat dilihat pada gambar 8:

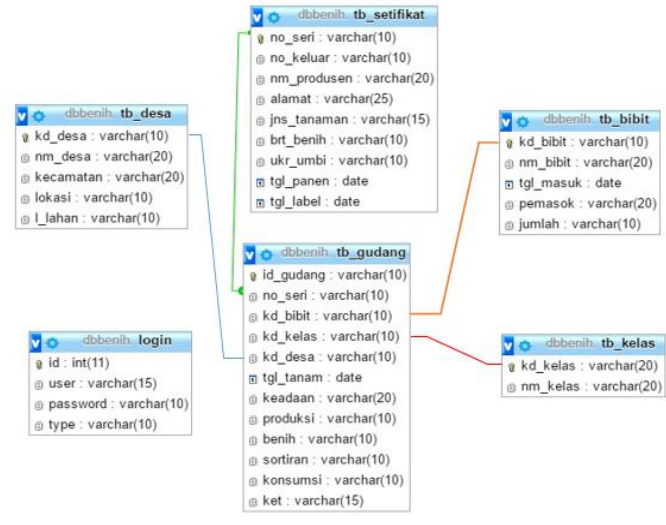

Gambar 8. Relasi File Sistem Informasi pembenihan pada balai benih induk (BBI) kentang Kabupaten Kerinci

1. Kode desa pada file desa behubungan dengan kode desa pada file gudang.

2. Nomor seri pada file sertifikat berhubungan dengan nomr seri pada file gudang.

3. Kode bibit pada file bibit berhubungan dengan kode bibit pada file gudang.

4. Kode kelas pada file kelas berhubungan dengan kode kelas pada file gudang.

\section{4. INFORMASI \\ IMPLEMENTASI}

SISTEM

Tahap implementasi merupakan tahap terakhir dalam menggambar sistem, yaitu meletakkan sistem supaya siap dioperasikan. Implementasi berguna untuk memudahkan penerapan sistem yang disiapkan agar pengentrian data sampai pada penyajian informasi sesuai dengan prosedur yang telah direncanakan.

Sebelum program diterapkan, program harus bebas terlebih dahulu dari kesalahan-kesalahan yang mungkin terjadi. Program diuji tiap-tiap modul dan dilanjutkan dengan pengujian ke semua modul yang telah dirangkai. Kesalahan yang mungkin terjadi dapat diklasifikasikan dalam tiga bentuk, yaitu sebagai berikut:

1. Kesalahan bahasa (language errors) atau disebut juga dengan kesalahan penulisan (syntax errors), adalah kesalahan dalam menulis penulisan source program yang tidak sesuai dengan yang sudah diisyaratkan.

2. Kesalahan waktu proses (runtime errors) adalah kesalahan yang terjadi sewaktu program dijalankan. Kesalahan ini akan menyebabkan proses program terhenti sebelum selesai pada saatnya karena compiler menemukan kondisi-kondisi yang belum terpenuhi yang tidak terbiasa dikerjakan. 
3. Kesalahan logika (logical errors), adalah kesalahan dari logika program yang dibuat setelah bebas dari kesalahan, dilanjutkan dengan pengujian sistem.

Tujuan utama dari pengujian sistem adalah memastikan bahwa elemen-elemen atau komponen-komponen dari sistem telah berfungsi sesuai dengan yang diharapkan.

Pengujian perlu dilakukan untuk mencari kesalahan-kesalahan atau kelemahan-kelemahan yang mungkin terjadi.

\section{Menu Login}

Halaman login bertujuan untuk membatasi hak akses admin atau user dalam menggunakan sistem yang ada. Dengan kata lain sistem ini hanya dapat digunakan oleh user tertentu yang sudah dikenal sistem. Dalam form ini dirancang beberapa tombol yaitu Ok dan Cancel. Tombol Ok berfungsi untuk masuk form menu utama setelah data yang diberikan valid. Tombol Cancel bergurna untuk membatalkan data pengguna yang sudah dientrikan.

\section{Menu Utama}

Halaman utama terdiri dari beberapa menu diantaranya : entri data, transaksi, laporan dan keluar. Masing-masing menu memiliki sub menu tersendiri dengan fungsi masing-masing. Menu pertama yaitu menu entri terdapat 43 sub menu yaitu adalah bibit, desa, dan kelas dan label. Menu kedua yaitu menu transaksi memiliki 12 sub menu diantaranya yaitu sertifikat dan gudang. Menu ketiga laporan memiliki 3 sub menu yaitu sertifikatlabel benih, laporan per bulan dan laporan per tahun. Menu yang terakhir yaitu keluar.

Dari beberapa menu dan sub menu diatas terdapat batasan akses. Semua menu diatas haya dapat diakses jika pengguna login sebagai adamin, namun jika pengguna melakukan login sebagai user ada beberapa menu yang tidak dapat di akses, diantaranya, entry dan transaksi

Untuk lebih jelasnya dapat di lihat pada gambar 9:

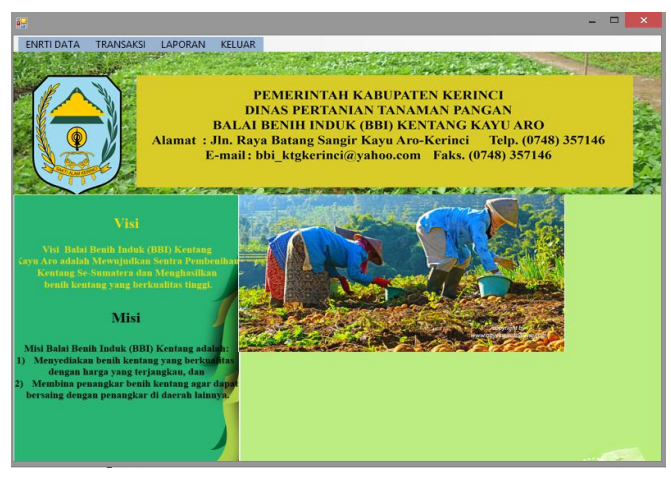

Gambar 9. Tampilan Menu Utama
3. Menu Input

Dalam sub menu input terdiri dari beberapa form entri data yang dibutuhkan oleh bagian Staf TU untuk pengolahan data pembenihan kentang. Form input tersebut terdiri dari data benih, data desa, data kelas daan data label yang dapat dilihat pada gambar berikut ini:

\section{a. Data Benih}

Form ini merupakan form untuk mengentrikan data benih. Data yang dientrikan adalah kode bibit, nama bibit, tanggal masuk, pemasok dan jumlah. Form input data benih pada sistem informasi pembenihan kentang pada balai benih induk (BBI) Kabupaten Kerinci dapat dilihat pada gambar 10:

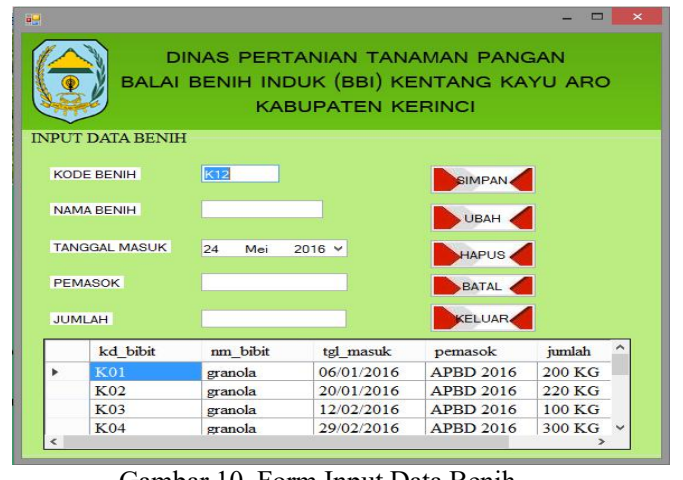

Gambar 10. Form Input Data Benih

\section{b. Data Desa}

Merupakan form untuk mengentrikan data desa. Data yang dientrikan adalah kode desa, nama desa, kecamatan, lokasi dan luas lahan. Form input data desa pada sistem informasi pembenihan kentang pada balai benih induk (BBI) kabupaten kerinci dapat dilihat pada gambar 11 berikut ini:

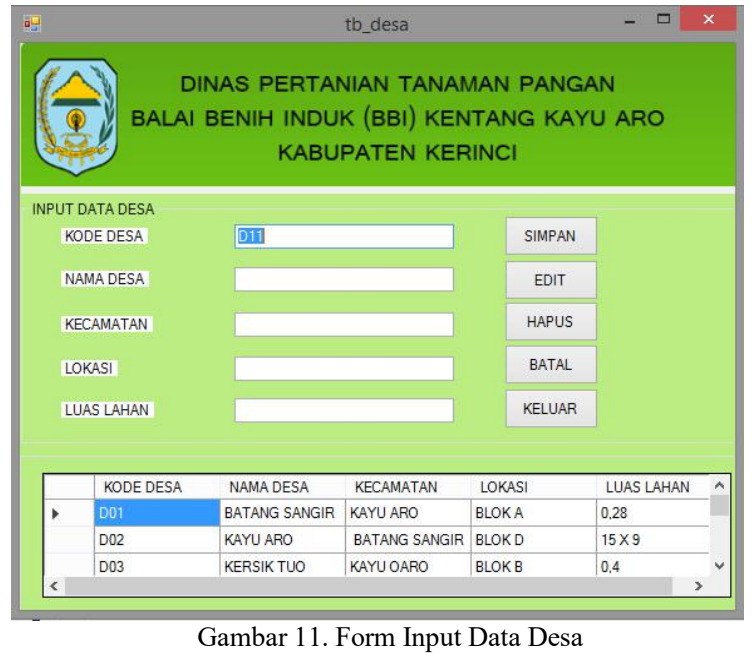


c. Data Kelas

Merupakan form untuk mengentrikan data kelas. Data yang dientrikan adalah kode kelas, nama kelas. Form input data kelas Pada Sistem Informasi Pembenihan Kentang Pada Balai Benih Induk (BBI) Kabupaten Kerinci dapat dilihat pada gambar 29. berikut ini:

\section{Menu Proses}

Pada form proses pengolahan data terdapat proses sertifikat benih dan laporan pembenihan. Pada proses ini bagian Staf TU mengentrikan data sertifikat dan data gudang untuk pembuatan laporan pembenihan.

\section{a. Data sertifikat}

Form data biaya ini berisikan nomor seri label, no keluar benih, nama produsen, alamat, jenis tanaman, berat bersih, ukuran umbi, tanggal panen, dan tanggal pemasangan label.

Form data biaya pada sistem informasi pembenihan kentang pada balai benih induk (BBI) kabupaten Kerinci.

\section{b. Data Gudang}

Form data biaya pemeliharaangudang ini merupakan form penampung semua data-data pembenihan. Form data biaya gudang ini berisikan data benih, data desa, data kelas dan data sertifikat Data yang dipanggil dari tabel lain adalah nomor seri label, kode bibit, kode desa, kode kelas.

\section{Menu laporan}

Dalam sub menu laporan terdiri dari beberapa modul yaitu label sertifikat benih, laporan perbulan dan laporan pertahun. Modul-modul laporan tersebut dapat dilihat pada gambar berikut ini:

\section{a. Sertifikat label Benih}

Bentuk dari sertifikat label benih seperti yang terlihat pada gambar 12 berikut ini:

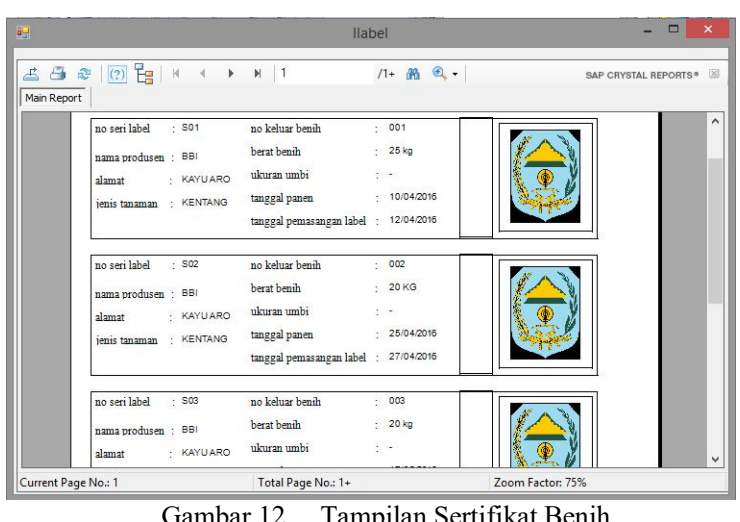

Bulan

b. Laporan Pembenihan Kentang Per

Sebelum laporan dimunculkan, maka akan tampil form penghubung laporan, seperti yang terlihat pada gambar 13 berikut ini:

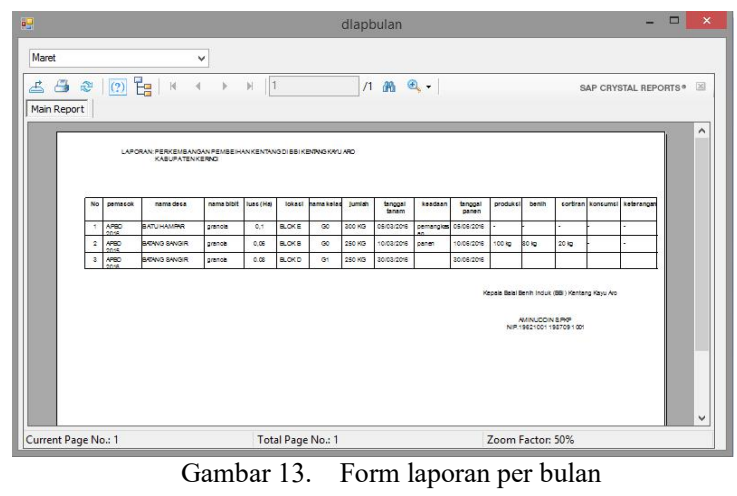

Pada form penghubung laporan pembenihan kentang per bulan tersedia parameter untuk menentukan laporan pada bulan berapa yang ingin kita cetak , maka akan ditampilkan pada monitor laporan pembenihan kentang berdasarkan bulan tanam kentang.

Adapun laporan pembenihan kentang per tahun berdasarkan tahun masuk APBD pada sistem informasi pembenihan kentang pada Balai Benih Induk (BBI) per tahun dapat di lihat pada gambar 14:

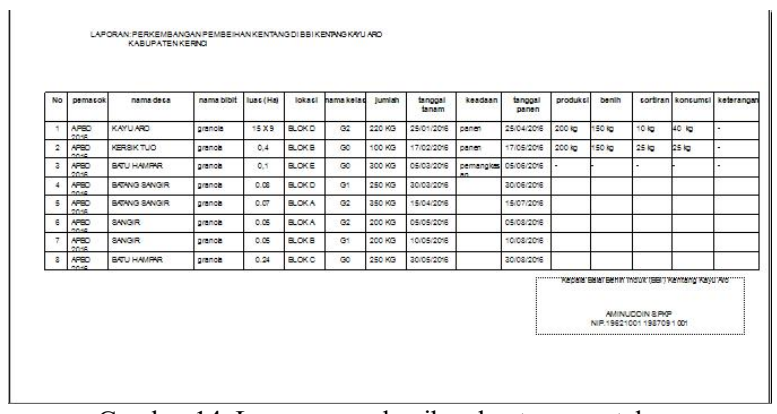

Gambar 14. Laporan pembenihan kentang per tahun

\section{KESIMPULAN}

Berdasarkan analisis dan pembahasan sebelumnya yang dilakukan pada sistem informasi pembenihan kentang pada balai benih induk (BBI) kentang maka dapat diambil kesimpulan, yaitu :

1. Cepatnya dalam merangkap laporan perkembangan pembenihan kentang karena sudah menggunakan bahasa pemograman Visual C\#.

2. Lebih mempermudah operator dalam mengentrikan data pembenihan kentang karena sudah ada primary key pada setip 
tabel, sehingga tidak terjadi lagi yang namanyaa penggandaan data.

3. Tidak membutuhkan waktu yang lama dalam pencarian data pembenihan kentang serta dalam pelaporannya.

Berdasarkan uraian sebelumnya dan batasan masalah yang dibuat pada penelitian ini, maka penulis dapat menggunakan beberapa saran sebagai berikut:

1. Untuk menjamin kelancaran jalannya sistem yang baru pada instansi balai benih induk (BBI) Kabupaten Kerinci, maka pihak instansi sebaiknya memberikan pelatihan pada pegawai yang bersangutan agar mampu menggunakan aplikasi sistem informasi pembenihan kentang Balai Benih Induk (BBI) kentang dengan baik.

2. Bagi pembaca di harapkan ada yang mengembangkan ke tingkat pengolahan data yang lebih detail.

3. Bagi pihak yang menggunakan diharapkan melakukan ujicoba terhadap sistem yang baru ini seperti tes data base, tes program sehingga dapat diketahui apakah sudah selesai dengan keinginan pemakai (user) dan layak untuk di terapkan.

4. Perlunya dilakukan pendekatan, pemeliharaan (maintenance) dan pengembangan sistem di masa yang akan datag utuk menjaga kelangsungan hidup sistem tersebut

5. Bagi peneliti berikutnya yang membahas masalah yang sama disarankan mengembangkan sistem lebih berkualitas, dimana peneliti harus menyempurnakan program aplikasi yang di buat dengan database yang lebih lengkap dan sebaiknya dapat membeuat website tersendiri bagi Balai Benih Induk (BBI) dalam pengolahan data pembenihan kentang sehingga bisa dilakukan kapan saja sesuai dengan kebutuhan masing masing-masing.

Demikian kesimpulan serta saran yang dapat penulis berikan pada akhir skripsi ini, mudah mudahan dapat menjadi bahan pemikiran bagi kita bersama, dan dapat mengejar ketertinggalan yang selama ini menjadi kelemahan kita semua.

\section{DAFTAR PUSTAKA}

[1] C. Paper and Z. Polg, "Integrated Information System of Potato Breeding and Qualification," no. May, 2005.
[2] H. Neeliah and H. Neeliah, "A Geographical Marketing Information System for Potato," April, 2016.

[3] Wharton, et. Al. A web-based interactive system for risk management of potato late blight in Michigan. Computers and Electronics in Agriculture 61(2):136-148, May 2008.

[4] Paristiyanti, (2008). Teknik Pembibitan Tanaman dan Produksi Benih. Direktorat Jenderal Manajemen Pendidikan Dasar dan Menengah.

[5] Kusrini dan Adri Xinio. (2007) Tuntunan Praktis Membangun Sistem Informasi Akuntasi Dangan Visual Basic Dan Microsoft SQL Server. Yogyakarta:Andi

[6] Fathansyah, (2012). Basis Data. Bandung:Informatika.

[7] Sutabri, Tata. (2012). Analisis Sistem Informasi. Yogyakarta:Andi Offiset.

[8] Sutabri, Tata (2012). Konsep Sistem Informasi.Yogyakarta:Andi Offset.

[9] Rusdiana Dan Moch Irfan. (2014). Sistem Informasi Manajemen. Bandung: Pustaka Setia

[10] Kadir,Abdul (2014). Pengenalan Sistem Informasi. Yogyakarta: Andi Offset

[11] Rosa Dan M. Shalahudin (2013) Rekaysa Perangkat Lunak Dan Berorientasi Objek. Bandung:Informatika.

[12] Jogianto.(2005). Analisis Dan Desain Sistem Informasi. Yogyakarta: Andi Offset.

[13] Supardi, Yuniar.(2010). Semua Bisa Menjadi Programer Visual Foxpro 2.0. Jakarta: Elex Media Komputindo. 